\title{
IDENTIFIKACE A INTERPRETACE MATERIÁLOVÉ, TECHNOLOGICKÉ A FUNKČNÍ PODSTATY MUZEJNÍHO SBÍRKOVÉHO PŘEDMĚTU JAKO VÝCHOZÍ BOD PRO DALŠÍ MUZEJNÍ ČINNOST ${ }^{1}$
}

\section{PAVLA STÖHROVÁ - MARIE ROSENFELD COHEN}

\section{ABSTRAKT/ABSTRACT:}

Součástí muzejní praxe je udržování tradičních, desítky let ověřených postupi̊ práce s kulturním dědictvím, sbírkami, archivním materiálem a informacemi, ale i nalézání nových cest $\mathrm{k}$ uchopení muzejního fenoménu. Důležité je, aby hmotná podstata muzeálií nebyla ohrožena a ochrana kulturního dědictví, jež stojí na čelním místě snah a smyslu muzejních institucí, jakkoliv limitována. $\mathrm{V}$ průběhu času muzejníci vyvíjejí různorodé př́istupy $\mathrm{k}$ práci se sbírkovými předměty odvozené od jejich stavu, materiálu, funkce a potřeby ochrany. Vznikají nejrůznější databáze, nové platformy a katalogizační systémy, které právě materiálovou podstatu a techniky zpracování a výroby považují za základ taxonomie a dalšího využití a prezentace sbírek. Tyto databáze a široce koncipované projekty spolupráce různých druhů pamětových institucí jednak zpřístupňují bohatství sbírek a kolekcí dokumentů všeho druhu, jednak pracují s historickým, společenským, ekonomickým a technologickým kontextem, který zároveň definují, interpretují a dále prezentačně využívají. Příkladem jsou populární př́stupy $\mathrm{k}$ prezentaci muzeálií a faktů prostřednictvím „vyprávění příběhů předmětư“, hledání souvislostí mezi předměty, historickými událostmi a osobnostmi. Současné přístupy $\mathrm{k}$ dokumentaci, identifikaci a interpretaci na takto nastíněné bázi jsou tématem tohoto př́spěvku, přičemž se opírají o vlastní empirii autorek, zkušenosti z projektů dokumentace a rekonstrukce technologických a výrobních postupů i sdílení informací $\mathrm{v}$ rámci mezinárodních muzeologických platforem, setkání a organizací.

Identification and interpretation of material, technological and functional substance of museum collection items as a starting point for other museum activities

An integral part of museum practice is the maintenance of traditional time-proved procedures of working with cultural heritage, collections, archival materials and information, as well as the search for new approaches to the museum phenomenon. It is important to not threaten the material substance of musealia and to not limit in any way the preservation of cultural heritage, which is one of the most important efforts and the sense of museum institutions. Over the course of time, museum workers develop various methods of working with collection objects, which are derived from their condition, material, function and need for preservation. Various databases, new platforms and cataloguing systems arise, according to which taxonomy and further use and presentation of collections are based on the material substance, processing and production techniques. These databases and broadly conceived cooperation projects of various types of memory institutions provide access to collections of all types of documents and are working with historical, social, economic and technological context which they at the same time define, interpret and use for presentation. An example thereof are popular methods of presenting musealia and facts by "telling stories of the objects" and by looking for the connections between objects, historical events and personalities. The topic of this paper are contemporary methods of documentation, identification and interpretation on the outlined basis. These approaches are based on the authors' empirical knowledge, on their experience acquired from the projects of documentation and reconstruction of technological and production procedures, and on information shared within the international museological platforms, meetings and organizations. 


\section{KLÍČOVÁ SLOVA/KEYWORDS:}

\author{
dokumentace - identifikace - \\ interpretace - muzeálie - sbírky - \\ rekonstrukce - funkcionalita - \\ technologie - ochrana kulturního \\ dědictví \\ documentation - identification - \\ interpretation - musealia - \\ collections - reconstruction - \\ functionality - technology - \\ preservation of cultural heritage
}

\section{Silné a slabé stránky současné muzejní identifikace a interpretace}

Pro muzejní dokumentaci a identifikaci je zásadní určení materiálové podstaty a způsobu výroby či vzniku muzejního předmětu. Pro jeho správný popis je třeba znát a fixovat informace o materiálech, ze kterých je zhotoven, o technologiích a postupech jeho výroby a zpracování, o jeho užití a funkčnosti, o estetických znacích atd. Všechny ty to komponenty jsou v procesu muzejního zpracování a péče využívány i $\mathrm{v}$ dalších muzejních činnostech - jsou neméně důležité pro stanovení postupu konzervace-restaurování, preventivní konzervace a uchování v podmínkách muzejních

depozitářro a expozic a samozřejmě při prezentaci (komunikaci). Cílem tohoto článku je představit, jak se jednotlivé „hlavní“ muzejní činnosti ovlivňují a jak na sebe navazují, a zejména pak, jak se toto jejich prolínání, pokud je individuálními pracovníky reflektováno, může odrazit ve kvalitě celkové muzejní práce. Ambicí autorek není tímto článkem definovat metodické postuláty, ale spíše poukázat na nutnost se jim podrobněji věnovat, protože zásadní práce z této oblasti jsou již staršího data a aktuální muzeologické diskuze na toto téma neprobíhají tak často, jak by si tato problematika zasluhovala. Rozsah článku neumožňuje vyčerpávajícím způsobem shrnout teoretická východiska. Volíme spíše jejich stručnou sumarizaci a osvětlení př́stupů kolegů, jež nás inspirují při řešení aktuálního výzkumného projektu. I pro tento projekt je charakteristická snaha podporovat propojení různých muzejních profesí podílejících se na procesu muzealizace a ochrany kulturního dědictví. Odráží se to i na struktuře článku, kdy se nejdříve postupně věnujeme jednotlivým muzejním činnostem (od dokumentace a identifikace po ochranu) a jejich roli, ve druhé části článku se pak více zaměřujeme na nečetné konkrétní příklady ilustrující nové přistupy, především ve vybraných a nám svou specializací blízkých muzeích, protože se domníváme, že právě informace o nich by mohla být pro kolegy podnětná. $V$ českém muzeologickém diskurzu diskuze zaměřená na „hodnotu“ předmětů nechybí, co však chybí, je její odraz v běžné každodenní muzejní práci a její komunikování směrem $\mathrm{k}$ laické veřejnosti.

Praxe $^{2}$ nám ukazuje, že kvalitní deskripce stávajících a dennodenně se rozrůstajících položek sbírkových evidencí je a zřejmě na dlouhou dobu zůstane torzovitá, záznamy v identifikačních kartách jsou a budou neúplné nebo často i nesprávné. Kurátoři a dokumentátoři mají z povahy svého pracovního zařazení za úkol rozšiřovat sbírkový fond promyšleně, na základě dlouhodobých sbírkotvorných (akvizičních) plánů, ale začasté musí rozhodovat o přijetí nových přírůstků i narychlo a flexibilně dle aktuální tržní nabídky,

2 Systematická evaluace současného stavu v této oblasti dosud nebyla provedena, nicméně rozvíjí se řada nástrojů pro zveřejňování obsahu sbírkových fondi̊ a jejich dokumentace. Tzv. on-line sbírky nám odhalují, do jaké šíře a v jaké kvalitě jsou jednotlivé položky (ne)správně určeny a popsány. Tuto poznámku však v žádném případě nezamýšlíme vůči on-line sbírkám a jejich správcům kriticky, naopak, sdílení informací ke sbírkám považujeme za správný krok umožňující další zpřesňování a doplňování stávající dokumentace. momentální poptávky v souvislosti s prezentační činností či v kontextu nových výzkumných záměrů apod. Průběžně zpracovávají desítky či stovky nových přírůstků do fondu, přičemž „vypsat kartu“ předmětu opravdu důsledně a kvalifikovaně vyžaduje široké spektrum znalostí a někdy mnohahodinové pátrání v informačních zdrojích. Součástí povinné péče je nepřetržitá inventarizace fondu, která je vhodnou př́iležitostí doplňovat stávající záznamy, podobně je tomu při práci se sbírkami na základě podnětu badatelů nebo kolegů využívajících fond $\mathrm{k}$ prezentačním aktivitám. Jinou možností je doplňování informací v rámci konzervátorské péče, tedy $\mathrm{v}$ těsné spolupráci kurátora příslušného fondu s konzervátorem.

Je nesporné, že personální kapacity v muzeích neumožňují v tuto chvíli ani důsledné a vyčerpávající zpracování nejnovějších fondů, natož doplňování neúplných evidenčních záznamů kolekcí starších, získaných předešlými kurátory a dokumentátory. Přesto zkušenosti a následováníhodné vzory už z některých institucí máme $\mathrm{k}$ dispozici, př́́kladem může být identifikace a reidentifikace kolekcí asijské provenience ve sbírkách zámků a pracovišst pod správou Národního památkového ústavu. ${ }^{3}$ Doplněná nebo opravená identifikace bývá též jedním $\mathrm{z}$ vedlejších produktů příprav prezentačních a publikačních výstupů, jež jsou prríležitostí vybrané fondy zevrubně zkoumat a předměty důkladněji popisovat ve spolupráci s dalšími profesemi z muzejní sféry nebo externími spolupracovníky (sběratelé, tvůrci a producenti, akademičtí pracovníci atd.). Je logickým a zřejmým faktem, že sběratelé,

\footnotetext{
3 Viz např. ČERNÁ, Zlata a Filip SUCHOMEL. Pưvaby orientálního salonu: umělecké řemeslo Dálného východu z jihomoravských a jihočeských zámeckých sbírek. Brno: Národní památkový ústav, územní odborné pracoviště v Brně, 2007.
} 
kteří se zabývají úzce vymezeným segmentem svého zájmu ${ }^{4} \mathrm{~s}$ vášní i časovou dotací přesahující možnosti muzejních pracovníků, mají mnohem detailnější znalosti o všech souvislostech vzniku a existence jednotlivin. Na druhou stranu se nezřídka setkáváme u současných kurátorů s obavami z doplňování, ba dokonce z oprav odborníků působících na jejich pozicích před nimi. Někdy s pietou až úzkostí považují specialisty nebo původní nabyvatele muzeálií do sbírek za držitele výlučné pravdy a neodvažují se připustit, že i oni se mohli mýlit, mít při akvizici informace nedostatečné, zavádějící nebo zcela nepravdivé. Limitující je i osobnostní výbava muzejního personálu, ne každý je ochotný přijmout skutečnost, že mýliti se je lidské a týká se i největších uctívaných kapacit svých oborů. Ne každý je také ochoten podstoupit fundovanou polemiku, své závěry obhajovat, nebo korigovat. A ještě mnohem složitější je to s případnou deakcesí, tedy vyřazováním $\mathrm{z}$ fondu za účelem jeho zhodnocení. Při tom již „nestorové“ muzeologického myšlení tato témata staví do popředí, ${ }^{5}$ stejně jako někteří muzeologové a literatura současná. ${ }^{6}$ Stručně formulované postuláty a postřehy by si jistě zasloužily konkrétnější ukotvení do širšího muzeologického kontextu, jež je však v tuto chvíli nad limitem námi vytyčených cílů a rozsahu článku.

4 Ekonomické konotace chybné identifikace při procesu autentizace (ověření pravosti) jsou rovněž zajímavou odbočkou, kterou se však v tomto textu nebudeme více zabývat. Diskuze nad nimi je bezesporu také žádoucí, a to nejen v rámci komerčního trhu s uměním a starožitnostmi, ale i při vyčíslování peněžní hodnoty „veřejného“ kulturního dědictví či akviziční politiky státu.

5 Především viz např. pojetí „informační kapacity muzejního sbírkového předmětu" u Josefa Beneše a jeho volání po interdiscciplinárním resp.

pluridisciplinárním př́istupu, nebo důsledné rozlišování mezi muzealizačním procesem a sběratelskou intencí v díle Z Z Z. Stránského. Např. BENEŠ, Josef. Muzeum a sbírky. Praha: Ústav pro informace a řízení v kultuře, 1977, s. 106-107.

6 Za všechny alespoň WAIDACHER, Friedrich. Príručka všeobecnej muzeológie. Bratislava:

Slovenské národné múzeum - Národné múzejné centrum, 1999, s. 98-103, 109-114, 207-213 aj.
Je třeba zdůraznit, že situace se liší také obor od oboru sbírkového zájmu. V některých vědních směrech je oblast materiálových a technologických průzkumů zásadní a velice rozvinutá, má mnohaletou tradici. Týká se to zejména archeologie, u které v centru pozornosti stojí nálezy a prameny neliterární povahy. Jejich hmotná podstata je nositelem informací využitelných pro další interpretaci předmětu a jeho kontextu. V rámci archeologického výzkumu se rozvinuly také subdisciplíny postavené výlučně na rozvoji poznání prostřednictvím znalostí materiálové a technologické situace lokality nebo časového úseku. Jde například o industriální archeologii (zkoumání výrobních metod a technologií archeologickými metodami) či experimentální archeologii. Pro použití v archeologickém výzkumu jsou také uplatňovány a vyvíjeny další a další dílčí metody, které poskytují zpřesnění popisu autentického dokladu minulosti a rozšiřují škálu toho, co nám je předmět sám o sobě a svém pưvodním kontextu „schopen vypovědět". Jedná se o metody využívající stále dokonalejší technické a přístrojové vybavení, nezřídka vyvíjené zároveň pro konzervátorskou a restaurátorskou praxi. Jmenujme například rozvíjející se průzkum materiálových analýz pomocí nedestruktivních metod. Rozvíjí se využití zobrazovacích a mikroskopických přístrojů pro tzv. komparační traseologii nebo tzv. materiálovou topografii povrchu. Již nějakou dobu jsou vědci schopni vyčíst $\mathrm{z}$ reziduí $\mathrm{v}$ zachovaných korozních a povrchových vrstvách řadu informací, na jejichž základě lze interpretovat nejen individuální „historii“ předmětu, ale i vyslovovat hypotézy o širším kontextu historické, antropologické nebo archeologické situace. ${ }^{7}$ Díky

7 Viz např. PEŠKA, Jaroslav, Miroslav KRÁLÍK a Alena SELUCKÁ. Rezidua a otisky organických těmto metodám jsme schopni zrekonstruovat způsoby opracování, použité nářadí či definovat orientační znaky a vodítka pro další identifikaci a rekonstrukci obrazu minulosti.

Podobný přístup je aplikovatelný nejen na archeologické prameny a kultury, ale i na ostatní oblasti muzejního fenoménu. Ve své výzkumné a dokumentátorské praxi se touto problematikou zabýváme také v Technickém muzeu v Brně ${ }^{8}$ ve spolupráci s Metodickým centrem konzervace. Dlouholetou tradici v muzeu mají workshopy, na nichž zkušení praktici z různých výrobních sektorů a řemesel spolu s muzejníky oživují a rekonstruují (polo)zapomenuté techniky a postupy, např. tavby železa, přípravy nástrojů a surovin, výroby damascénské oceli, povrchových úprav kovů atd. Výsledky těchto výzkumů slouží i k další prezentační činnosti, příkladem čehož je rozsáhlý projekt Smalt/Email probíhající v minulých letech. ${ }^{9} \mathrm{~V}$ roce 2020 byl zahájen projekt „Uměleckořemeslné techniky zlatnictví - identifikace, ochrana a zpřistupnění“. ${ }^{10}$ Jeho cílem je vyvinout nástroj pro správnou identifikaci a ochranu historických technik a způsobů

látek v korozních produktech mědi a jejích slitin. Pilotní studie. Industrie starší doby bronzové. Památky archeologické, 2006, roč. 97, s. 5-46.

8 Aktuálním rozsáhlým publikačním

a metodickým počinem k této problematice je certifikovaná metodika jako výstup z konsorcionálního projektu NAKI II řešeného ve spolupráci Národního památkového ústavu a Technického muzea v Brně „Průmyslové dědictví z pohledu památkové péče“. Viz např. MERTOVÁ, Petra. Metodika ochrany průmyslového dědictví muzejními prostředky. Ostrava: Národní památkový ústav, 2019. Vyšlo i v anglické jazykové mutaci.

9 Experimentální rekonstrukce emailérských technik. In Metodické centrum konzervace [online]. Brno: Technické muzeum v Brně, 2017 [cit. 2020-05-13]. Dostupný z www: $<$ https://mck.technicalmuseum.cz/smalt/frame4. html>.

10 Uměleckořemeslné techniky zlatnictvíidentifikace, ochrana, zpř́stupnění [online]. Brno: Technické muzeum v Brně, 2020 [cit. 2020-05-13]. Dostupný z www: <http://www.technicalmuseum. cz/veda-vyzkum/projekty-granty/

umeleckoremeslne-techniky-zlatnictvi/> 
zpracovávání kovových materiálů aplikovaných u nejrůznějších artefaktů, které tvoří nejen v České republice nejcennější kolekce kulturního dědictví. Užitečnou pomůckou vzešlou z projektu bude památkový postup obsahující nové interpretace a zhodnocení řemeslného zpracování na základě charakteristických výrobních znaků doložených rekonstrukcemi technik i výrobních nástrojů, výsledky přírodovědných analýz zkoumaných materiálů a průzkumem autentických artefaktů. Zkvalitnění metodologie určování a datace předmětů přispěje $\mathrm{k}$ jejich správnému zařazování do muzejních sbírek i odhalování falsifikátů, při procesech konzervace a restaurování napomůže při plánování postupů zásahů s dưrazem na užití reverzibilních a kompatibilních metod s původními historickými řemeslnými technikami.

Stále je však také potřeba prohlubovat využití ikonografických a literárních pramenů, které mohou i dnes poskytnout řadu informací o technologickém pokroku a materiálech toho kterého období. ${ }^{11}$ Archivní prameny, dobová literatura apod. ukrývají informace o stupni soudobého poznání a díky nim je možné i přesně definovat mezníky, které mohou být vodítky například pro časovou posloupnost a ověřování datace. Tyto zdroje samozřejmě nemohou všechny znát a umět „číst", tedy používat a na jejich základě interpretovat, všichni kurátoři zodpovědní za kvalitní popis a identifikaci. To už přesahuje odbornou kapacitu jedince. Je však možné a nutné nabyté know-how efektivně a koordinovaně sdílet, a tím bude i umožněno, aby se nevynakládaly veřejné prostředky

\footnotetext{
11 Je potěšující, že exponenciálně roste počet digitalizovaných a veřejně přístupných zdrojů archivní povahy, které toto klasické historické bádání nevídaným způsobem rozšiřuje a zefektivňuje, nicméně vytěžení těchto zdrojů je stále závislé na personálních možnostech a individuálních limitech badatelů.
}

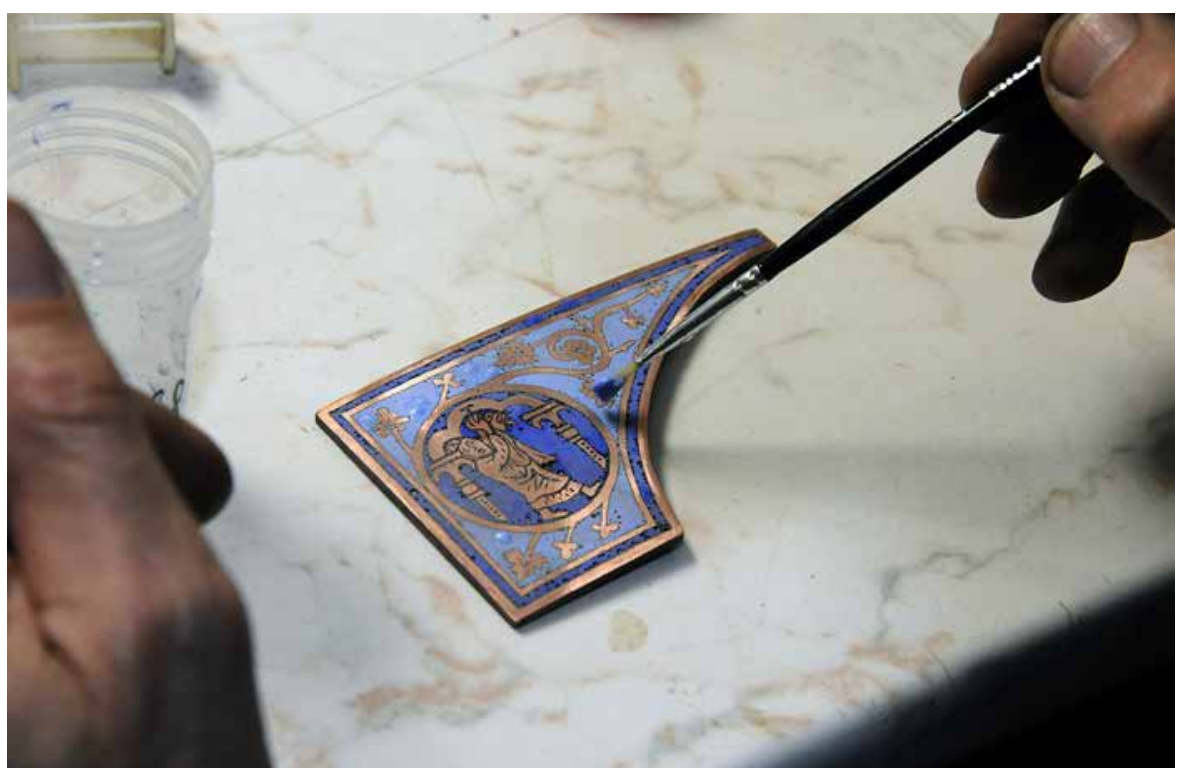

Obr. 1: Záběry z workshopu emailérských technik v Technickém muzeu v Brně v roce 2019. Foto: Eva Řezáčová (Technické muzeum v Brně).

dvakrát na stejné výzkumné téma, ale naopak, aby byl vědecký výstup opakovaně a efektivně sdílen širokým spektrem uživatelů. V muzejní praxi to znamená např. připravit a sdílet kvalitní metodické návody a příručky, které orientaci $\mathrm{v}$ problematice maximálně usnadní. ${ }^{12}$

Jak již bylo řečeno, výše nastíněné možnosti, jak zlepšit muzejní dokumentaci a identifikaci, jsou vyvíjeny a využívány zejména v souvislosti s oblastí péče o předměty a je potřebné seznamovat se závěry těchto průzkumů i další muzejní specialisty, naučit využívat je muzejní kurátory a dokumentátory při jejich akviziční a identifikační praxi - při procesech muzejní selekce a tezaurace. Znalost v této oblasti pomůže všem muzejním profesím, ale i veřejnosti využívající muzejní sbírky, lépe předmět

\footnotetext{
$12 \mathrm{~V}$ tomto směru se podařilo prosadit několik výzkumných projektů na toto téma i v české vědě, příkladem může být aktuálně řešený projekt konsorcia institucí Reč materiálu. Tradiční řemeslné technologie pro záchranu kulturního dědictví a současný životní styl [online]. Praha: Filozofická fakulta Univerzity Karlovy, 2020 [cit. 2020-05-13]. Dostupný z www: $<$ https://www.recmaterialu.cz/cs/ $>$.
}

popsat, datovat, ověřit jeho pravost, využít jeho potenciálu pro další aktivity, při výzkumu i prezentaci. Jen správně a řádně popsané předměty má smysl zařazovat do konvolutu sbírek. A jen s tímto vědomím sestavované sbírky lze považovat za opravdovou muzejní dokumentaci. Pouze neustálým zdokonalováním procesu identifikace jak nových akvizic, tak stávajících sbírek, jsme schopni zanechat budoucím generacím kulturní dědictví jako vypovídajícího svědka minulosti. Rezignace na zkvalitňování tohoto procesu v dlouhodobém horizontu vede $\mathrm{k}$ nevratným ztrátám. Pokud se z individuální i kolektivní paměti vytratí technologická znalost, je její obnova bud' téměř nemožná, nebo možná jen omezeně a za vysokou ekonomickou cenu.

Příklady využití procesu muzejní dokumentace, ochrany sbírek a zachování jejich funkčního potenciálu v prezentačních aktivitách muzeí

Mnoho odborníků samostatně, ale i v rámci různých skupin a platforem, jakou jsou například odborné komise 
Mezinárodní rady muzeí ICOM, se stále více zabývá způsoby propojení ochrany sbírkových předmětů se zachováním jejich funkčnosti a následnou prezentací. ${ }^{13}$ Aktuálním tématem na diskuzních fórech a v programech mezinárodních konferencí je například provoz originálních strojů či nástrojů a výroba a využívání jejich kopií, udržitelnost materiálì, způsoby, jak tyto materiálny nahradit, problematika uchování dotýkaných předmětů a také otázka, jak pracovat s autenticitou předmětu a přitom zaujmout různé skupiny návštěvníků a zároveň uspokojovat potřeby badatelů. ${ }^{14}$

Autenticita a funkčnost předmětu a „zpráva“, kterou předmět svojí funkčností autenticitu předává, jsou jedním z rezonujících témat současné muzeologie. Zevrubně se jí zabývaly například odborná komise pro hudbu a hudební nástroje CIMCIM a odborná komise pro muzea a sbírky vědy a techniky CIMUSET počátkem roku 2020 na společném setkání v Paříži. ${ }^{15}$ Snahou zúčastněných bylo najít průsečík teoretických poznatků a aktivit, které mohou být přínosné pro odborníky z obou těchto oborových skupin. Společným tématem bylo rozpohybovávání a „rozeznívání (a to $\mathrm{v}$ případě hudebních muzeí/ nástrojů doslova) sbírkových předmětů. Propojení obou dosti vzdálených témat se může na první pohled jevit jako problematické

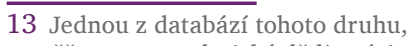
zaměřenou na technické dědictví, je například italská databáze Archivi della Scienza

(www.archividellascienza.org), vznikající ve spolupráci italské Národní akademie vědy a techniky a Museo Nazionale della Scienza e Technologia Leonardo da Vinci a také ministerstva kultury či archivních institucí. 14 Naposledy viz např. ŘEZNíčKOVÁ, Viera. Vliv autenticity na percepci exponátu. Museologia Brunensia, 2019, roč. 8, č. 2, s. 46-48.

15 Jouer et actionner les instruments des collections patrimoniales [online]. Paris: Philharmonie de Paris, 2020 [cit. 2020-05-14]. Dostupný z www: <https://philharmoniedeparis.fr/en/ activity/colloque/21277-jouer-et-actionner-lesinstruments-des-collections-patrimoniales $>$. (také s ohledem na nízký počet zástupců technických muzeí dosud vstupujících do podobných diskuzí), nicméně se našlo mnoho průsečíků, které přinesly nové poznatky pro kurátory a odborníky z obou odvětví a typů muzejních institucí.

Frank P. Bär z Germanisches Nationalmuseum se na setkání ohlédl za vývojem přístupu $\mathrm{k}$ hudebním nástrojům jakožto primárně znějícím předmětům. Zjistil, že mezi lety 1967 až 2002 můžeme sledovat tendence odstupu od jejich restaurování a příklon ke konzervování, přičemž nebezpečí jejich rozeznívání bylo hojně zdokumentováno. Stále však chybí odpovědi na základní otázky týkající se naopak pozitivního dopadu užívání těchto předmětů k takovým účelům, k jakým byly primárně vytvořeny. $\mathrm{S}$ podobnými problémy a otázkami se potýkají i kolegové z komise CIMUSET, kteří ve spolupráci právě s Frankem P. Bärem započali $S$ přípravou společného manuálu a doporučení pro muzea a sbírky vědy a techniky.

\section{K diskutovanému tématu} interpretace funkčních objektů se vztahuje také myšlenka vnímání a následné prezentace sbírkových předmětů jako nositelů příběhů, nejen funkčnosti. Předměty se různými cestami od původních majitelů dostávají do muzejních sbírek, kde zažívají jakožto tzv. dotýkané předměty další interpretaci, přičemž i ony „cesty“ je třeba zohledňovat. Př́ikladem mohou být hudební nástroje, na které hráli afroameričtí

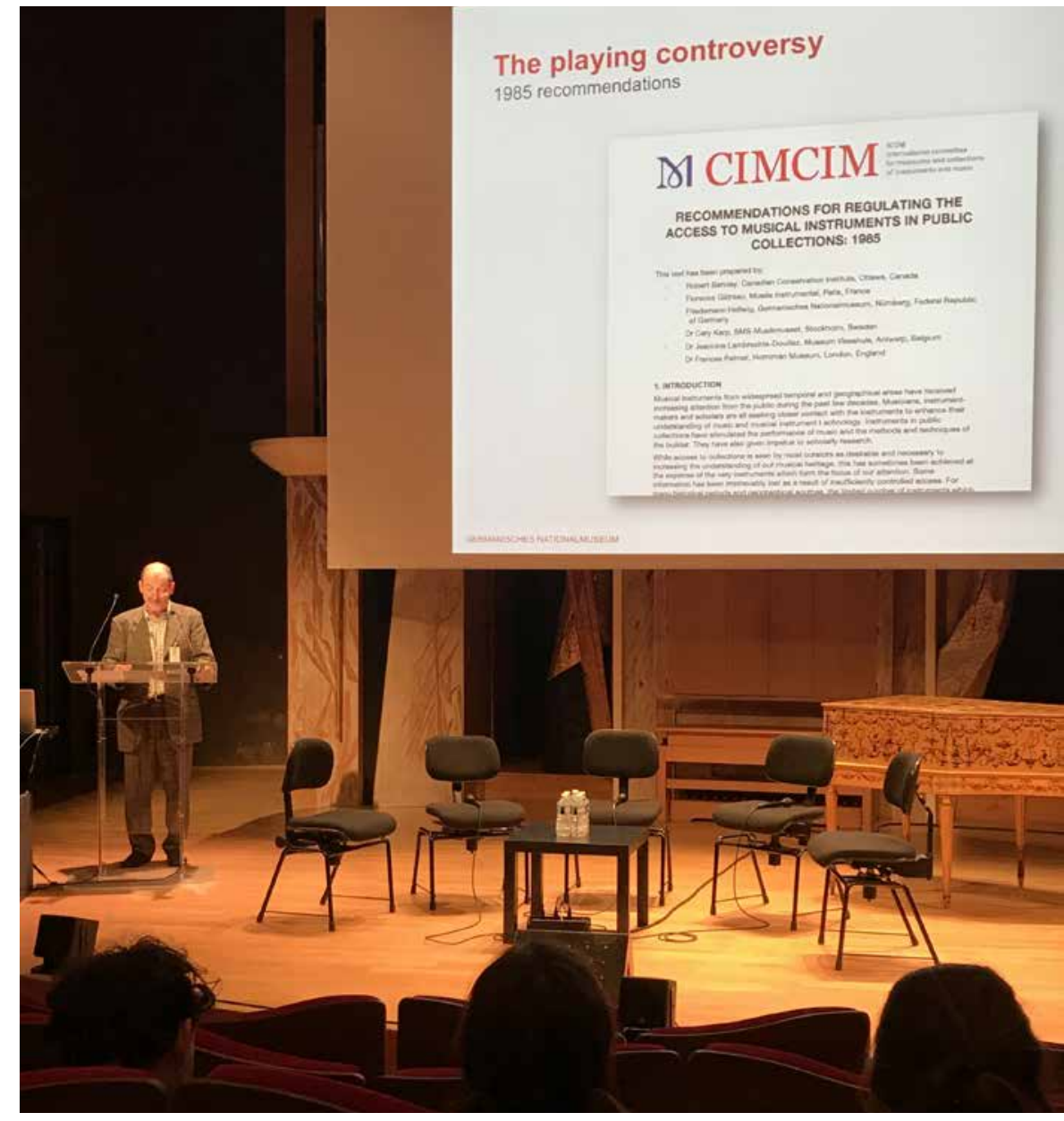

Obr. 2: Frank P. Bär na paří̌̌ském kolokviu, prezentující výsledky výzkumu komise CIMCIM. Foto: Marie Rosenfeld Cohen (Technické muzeum v Brně). 
prristěhovalci v Americe a vstupují tak do různých kontextů; ${ }^{16}$ či vzácné housle, při jejichž konzervaci a restaurování byla uvažována otázka dalšího „rozeznívání“ a užívání v muzejním prostředí.

Zatímco u hudebních nástrojů se primárně jedná při rozhodovacím procesu, který předchází konzervátorsko-restaurátorskému zásahu, o zachování původního zvuku, nikoli nutně stejného vzhledu, u předmětů ze sbírek technických muzeí se řeší funkčnost při zachování původního stavu předmětu. Prezident komise CIMUSET Ech Cherki Dahmali např́ílad prezentoval úskalí, se kterými se potýkali při vytváření nové stálé expozice telekomunikace v Morocco Telecom Museum v Rabatu. Muzeum oslovilo odborníky, kteří již v oboru nepracují, aby pomohli při obnovování chodu telefonních přístrojů v muzeu. Nejednalo se o výrobu kopií, ale co nejširší využití originálů. Kurátoři si od bývalých techniků osvojovali ovládání těchto prrístrojů, což bylo klíčové i při jejich následné prezentaci veřejnosti. V japonském muzeu automobilové firmy Toyota, ${ }^{17}$ které vzniklo z firmy na výrobu tkalcovských strojů, je návštěvníkům zpř́ístupněna stálá expozice tkalcovských strojů využívající jak originálů (jedná se převážně o tkalcovské stavy z odolných materiáli̊n, které již byly vyráběny $\mathrm{z}$ kovu), tak kopií (u vývojově starších modelů ze dřeva). Primární totiž byla nikoliv statická prezentace, ale možnost rozpohybování předmětů, kterého se ujali prezentátoři.

16 Viz A People's Journey, A Nation's Story [online]. Washington, DC: Smithsonian National Museum of African American history \& Culture [cit. 2020-05-14]. Dostupný z www: < https:// nmaahc.si.edu/>.

17 Viz Spirit of Research and Creativity. Pass on the importance of crafting to the next generation [online]. Nagoya: Toyota Commemorative Museum of Industry and Technology [cit. 2020-05-14]. Dostupný z www: <http://www.tcmit.org/ english $>$.
Při výrobě funkčních kopií a rekonstrukcích originálních předmětů nebo jejich částí jsou využívány moderní neinvazivní způsoby založené na počítačových technologiích a simulacích. Tzv. virtual instruments představil Byron Pillow z National Music Museum ve Spojených státech. Pro vytvoření nahrávky zvuků nástroje využívají fyzické modelace nástroje např. 3D technologiemi a jejich doplněním o plány konstrukce nástroje, řezu předmětu atd. Výsledkem je vytvoření virtuálního nástroje a simulace jeho zvuku. V muzejních expozicích pak lze umístit multimédia různých forem a přehrávat nahrávky. Ve francouzském Museé de la Musique vznikl zajímavý projekt také za využití již zmíněného 3D tisku a to při rekonstrukci kostěné flétny z 15. století ze sbírek muzea. Tyto techniky dovolují za velice nízké náklady vytvářet kopie, které lze masivně využívat při prezentacích, a zároveň maximálně ochraňují předměty během manipulace při výzkumu, což by nečetné zachované originály mohlo nevratně poškodit.

Éric de Visscher z výzkumného institutu Victoria and Albert Museum v Londýně představil na setkání komisí př́ispěvek na téma „Nástroje a predměty zapojení s pomocí funkčních muzejních predmětů skrze narativitu a teatrálnost “. V něm se zabýval př́iběhy, které muzejníci skrze sbírkové předměty sdělují, a způsoby, jakými se je snaží učinit relevantními pro návštěvníky ze současnosti. Ukazuje se, že nejčastějším tématem hudebních muzeí a muzeí hudebních nástrojů jsou rekonstrukce těchto nástrojů a jejich následná autenticita a potenciál sdělnosti nového zvuku poskytnutého kopiemi předmětu. Ve stejném kontextu lze rozvíjet teoretické úvahy o úloze původních předmětů pro současnost a naopak nových kopií například u fotografií, zvukových záznamů či videí zachycujících pohyb předmětů. Problematice nového způsobu jejich vnímání se v současnosti věnují např. v Egyptském muzeu v Káhiře, v École du Louvre v Paříži nebo University of London.

Je nepochybné, že s rozvojem informačních technologií bude pokračovat vývoj směřující k rozeznívání/rozpohybovávání (hudebních - ale nejen jich) předmětů/nástrojů a jejich interpretace $\mathrm{v}$ digitálním světě. Kolegové z technických muzeí v Kanadě (Ingenium - Kanadské muzeum vědy a techniky) aktuálně prezentovali příklad ze svých sbírek - zcela nefunkční syntetizér, údajně první na světě, který se ale nezachoval kompletní a ani není zachován jeho záznam. Je tedy nutno zcela od základu vytvořit způsob, jak tento předmět opět rozeznít. Jde o typický př́íklad toho, jak muzejníci řeší otázku, do jaké míry lze zrekonstruovat funkci a zvuk předmětu, u něhož je neznámá finální podoba a u něhož neznáme výsledný zvuk z žádného záznamu, často nejsou známy ani podobné předměty, ze kterých lze na základě analogie podobu a zvuk vydedukovat. Velice hodnotnými a praktickými mohou být příklady dobré praxe obnovy a ochrany či konzervace a restaurování sbírkových předmětů s důrazem na zachování jejich hodnoty. Nina Robbins ${ }^{18}$ z University of Helsinki např́klad vytvořila metodický nástroj pro muzejní pracovníky, který má pomoci stanovit rovnováhu mezi hodnotou funkčnosti předmětů a jejich prezentací pro veřejnost. Robbins uvádí, že pochopení pojmu "diskuze muzeologické hodnoty“ pomůže muzejním odborníkům lépe rozlišit témata $\mathrm{v}$ každodenní práci zaměřená na otázku hodnoty

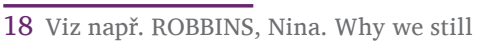
need collections - Museums in the business of originality. In ICOFOM Study Series, 2020, sv. 48-1, s. 183-192. 
předmětu. Upozorňuje na potřebu pracovníků v muzeích se aktivně a osobně účastnit v těchto diskuzích, zaměřených primárně na hodnoty předmětů, v souvislosti $s$ jejich dalším využíváním, udržitelností a dlouhodobou ochranou. Jistě bude zajímavé i pro teoretiky tyto diskuze zachytit a rozvíjet i v českém muzeologickém diskurzu.

Příklady dobré praxe při obnovování předmětů mohou inspirovat např́iklad při volbě konzervačních postupů a obnově mechanismů u technických sbírek. Vzhledem k tomu, že klíčovou vlastností mnoha těchto typů předmětů je pohyb, jenž napomáhá celkovému pochopení jejich funkčnosti, často je zvolen postup konzervování „za pochodu“ a při udržení pohyblivosti předmětu. Výběr metody konzervace - za pochodu nebo ve statickém režimu - je nejvhodnější odvozovat na základě zkoušek a analytických technik, adaptovaných na pohyblivé předměty. Adrian v. Steiger z Hochschüle der Künste v Bernu toto téma zpracovává $\mathrm{v}$ souvislosti s využíváním a vývojem nových analytických metod, jako jsou XRF a Ramanova spektroskopie, ultrazvukové testování či vibrační analýzy. ${ }^{19}$ Rovněž jeho závěry bude zajímavé do budoucna sledovat a informovat o nich $\mathrm{v}$ českém prostředí.

\section{Závěrem - rekapitulace současných výzev}

Vycházejíc z výše uvedených př́íkladů i současné praxe $\mathrm{v}$ muzejní instituci lze definovat, jakým okruhům témat je potřeba se věnovat $\mathrm{v}$ oborové diskuzi týkající se muzejní dokumentace, identifikace a interpretace. Tato témata by

19 Bibliografický soupis publikační činnosti Adriana v. Steigera k tomuto tématu Publikationen Dr. Adrian v. Steiger [online]. [cit. 2020-05-14]. Dostupný z www: < https://www.hkbinterpretation.ch/fileadmin/user_upload/ documents/Personen/Publist_AvS.pdf $>$. bylo vhodné komunikovat a dále teoreticky rozpracovávat například $\mathrm{v}$ rámci projektů výzkumu a rozsáhlejších prezentačních aktivit jako př́íladové nebo modelové studie, jako jakési „ponaučení“ z praxe. Kurátoři a další odborní pracovníci muzeí by tak získali pro svoji odbornou práci sofistikovaný nástroj, na jehož základě mohou svoji práci zkvalitňovat. Napomohl by také $\mathrm{v}$ záměru veřejnosti atraktivně a efektivně přibližovat význam uchovávání kulturního dědictví. Mezi specialisty zabývajícími se sbírkovými předměty $\mathrm{z}$ různých pohledi̊ a např́č všemi obory totiž nejčastěji rezonuje otázka, jakým způsobem co nejšetrněji a nejautentičtěji zpřístupnit návštěvníkům pưvodní předměty tak, aby byly ochráněny pro budoucí generace a zároveň uchovávaly svůj původní účel a funkci, „svůj zvuk a pohyb“. Bez důkladného poznání hmotné podstaty předmětu a způsobu jeho výroby to ovšem nepůjde, což je také důvodem $\mathrm{k}$ zaměření pozornosti pracovníků Technického muzea v Brně a Metodického centra konzervace na rekonstrukci historických postupů výroby a technologií opracování a povrchových úprav užívaných v minulosti. Je nezbytné, aby nedílnou součástí podobně koncipovaných projektů byla i reflexe muzeologických přístupů.

\section{SEZNAM POUŽITÝCH ZDROJŮ A LITERATURY:}

A People's Journey, A Nation's Story [online]. Washington, DC: Smithsonian National Museum of African American history \& Culture [cit. 2020-05-14]. Dostupný z www: <https://nmaahc.si.edu/>.

BENEŠ, Josef. Muzeum a sbírky. Praha: Ústav pro informace a řízení v kultuře, 1977.

ČERNÁ, Zlata a Filip SUCHOMEL. Půvaby orientálního salonu: umělecké řmemeslo Dálného východu z jihomoravských a jihočeských zámeckých sbírek. Brno: Národní památkový ústav, územní odborné pracoviště v Brně, 2007. ISBN 978-80-86752-53-2.

Experimentální rekonstrukce emailérských technik. In Metodické centrum konzervace [online]. Brno: Technické muzeum v Brně, 2017 [cit. 2020-05-13]. Dostupný z www: <https://mck.technicalmuseum. cz/smalt/frame4.html>.

Jouer et actionner les instruments des collections patrimoniales [online]. Paris: Philharmonie de Paris, 2020 [cit. 2020-05-14]. Dostupný z www: <https://philharmoniedeparis. fr/en/activity/colloque/21277-joueret-actionner-les-instruments-descollections-patrimoniales $>$.

MERTOVÁ, Petra. Metodika ochrany průmyslového dědictví muzejními prostředky. Ostrava: Národní památkový ústav, 2019. ISBN 978-80-88240-14-3 (NPÚ), ISBN 978-80-87896-79-2 (TMB).

PEŠKA, Jaroslav, Miroslav KRÁLÍK a Alena SELUCKÁ. Rezidua a otisky organických látek v korozních produktech mědi a jejích slitin. Pilotní studie. Industrie starší doby bronzové. Památky archeologické, 2006, roč. 97, s. 5-46. ISSN 0031-0506.

Publikationen Dr. Adrian v. Steiger [online]. [cit. 2020-05-14]. Dostupný z www: <https://www.hkb-interpretation.ch/ fileadmin/user_upload/documents/ Personen/Publist_AvS.pdf $>$.

ROBBINS, Nina. Why we still need collections - Museums in the business of originality. In ICOFOM Study Series, 2020, sv. 48-1, s. 183-192. ISBN 978-2-491997-11-3. https://doi.org/10.4000/iss.2210

Řeč materiálu. Tradiční řemeslné technologie pro záchranu kulturního dědictví a současný životní styl [online]. Praha: Filozofická fakulta Univerzity Karlovy, 2020 [cit. 2020-05-13]. Dostupný z www:

<https://www.recmaterialu.cz/cs/>. ŘEZNíČKOVÁ, Viera. Vliv autenticity na percepci exponátu. Museologia Brunensia, 2019, roč. 8, č. 2, s. 46-48. ISSN 1805-4722. https://doi.org/10.5817/MuB2019-2-5

Spirit of Research and Creativity. Pass on the importance of crafting to the next generation [online]. Nagoya: Toyota Commemorative Museum of Industry and Technology [cit. 2020-05-14]. 
Dostupný z www: < http://www.tcmit. org/english/>.

Uměleckořemeslné techniky zlatnictvíidentifikace, ochrana, zpřistupnění

[online]. Brno: Technické muzeum v Brně, 2020 [cit. 2020-05-13]. Dostupný z www: <http://www.technicalmuseum. cz/veda-vyzkum/projekty-granty/ umeleckoremeslne-technikyzlatnictvi/>
WAIDACHER, Friedrich. Príručka

všeobecnej muzeológie. Bratislava:

Slovenské národné múzeum - Národné múzejné centrum, 1999.

ISBN 80-8060-015-5.

\section{PAVLA STÖHROVÁ}

Technické muzeum v Brně, Brno, Česká republika

stohrova@tmbrno.cz

Vystudovala etnologii a muzeologii na Filozofické fakultě Masarykovy univerzity v Brně a od roku 1999 pracuje v Technickém muzeu v Brně, nejdřive na pozici odborného pracovníka - kurátora (obor technika domácnosti, expozice Ulička řemesel TMB), v současnosti má na starosti ediční a vědeckovýzkumnou činnost. Úzce spolupracuje s Metodickým centrem konzervace. Autorsky nebo editorsky se podílela na celé řadě výstavních projektů a publikací, v poslední době např́iklad „Uměni emailu/Technika smaltu“, „Karátové duše“, „Až na kov!“.

She graduated in ethnology and museology at the Faculty of Arts, Masaryk University in Brno.

Since 1999, she has been employed in the Technical Museum in Brno, first as a member of professional staff - curator (the field of domestic technology, permanent display A Lane of Crafts, Technical Museum in Brno) and now she is responsible for editorial activity and scientific research. She closely collaborates with the Methodical Centre for Conservation. She co-authored and co-edited many exhibition projects and publications, recently for example "The Art of Enamelling/The Enamelling Technique", "Carat Souls", "Až na kov!" (To the Metal!).

\section{MARIE ROSENFELD COHEN}

Technické muzeum v Brně, Brno, Česká republika

gilbertova@tmbrno.cz

Vystudovala etnologii a muzeologii na Filozofické fakultě Masarykovy univerzity v Brně a od roku 2011 pracuje v Technickém muzeu v Brně jako kurátorka (obory řemesla, vodní mlýny, vodárenství a vodní stavby). Je odborným garantem národní kulturní památky Vodní mlýn ve Slupi. Podílela a podílí se na řadě výstavních projektů v TMB (např. Umění emailu/Technika Smaltu, Robot2020), pravidelně publikuje v odborných časopisech na témata řemesel a brněnského industriálního dědictví. Od roku 2012 je členkou komise ICOM - CIMUSET (Komise pro muzea a sbírky vědy a techniky). Od roku 2016 je členkou předsednictva komise. Od roku 2020 je také členkou předsednictva Českého výboru ICOM a podílí se na přípravě Generální konference ICOM v roce 2022 v Praze.

She graduated in ethnology and museology at the Faculty of Arts, Masaryk University in Brno. Since 2011, she has been working in the Technical Museum in Brno as a curator (the fields of crafts, watermills, water management and hydraulic engineering). She is professional guarantor of the national cultural monument Watermill in Slup.
She participated and still participates in many exhibition projects of the Technical Museum in Brno (e.g. The Art of Enamelling/The Enamelling Technique, Robot2020), regularly publishes articles in professional journals on the topics of crafts and Brno industrial heritage. Since 2012, she is member of the ICOM CIMUSET committee (International Committee for Museums of Science \& Technology) and presidium member since 2016. Since 2020, she also is presidium member in the ICOM Czech National Committee and participates in preparation of the 2022 ICOM General Conference in Prague. 